\title{
Comparison of bivalves of Family Pinnidae from Southern Vietnam: A morphometric approach
}

\author{
Alla V. Silina \\ A.V. Zhirmunsky Institute of Marine Biology, Far East Branch, Russian Academy of Sciences, Vladivostok 690059, Russia
}

\begin{abstract}
Comparison of different morphological characteristics of bivalves is very useful for distinguishing species. Therefore, this study used a morphometric approach to document patterns of phenotypic change through the specimens of family Pinnidae inhabiting the bottom sediments at the coasts of An Thoi Archipelago (south-eastern Gulf of Thailand), in that way excluding intraspecific variations among different populations along a wide geographical range. It was revealed that individuals determined as Pinna trigonium separated from specimens of Pinna nigra and Atrina vexillum at high level, but $P$. nigra and $A$. vexillum were the single species $A$. vexillum, as it is assumed now. Also, it was found that both groups of $P$. trigonium individuals and $A$. vexillum specimens divided into tree subgroups unified the specimens with the similar morphometric parameters: small, medium and large within the populations, though there were no evident divisions into subgroups in the size distributions of the populations. In addition to the interspecific morphological variations, the species also showed significant intraspecific morphological variations even in the same population. Most probable reason for the appearance of the intraspecific morphological variations and division of all specimens into size-specific subgroups in the population is the fact that the growth of Pinnidae bivalves is not isometric.
\end{abstract}

Key words: Pinna trigonium, Atrina vexillum, Gulf of Thailand, populations, growth, bivalves, mollusks, shells

\section{INTRODUCTION}

The family Pinnidae Leach, 1819 consists of the single genus Pinna Linne, 1758, which comprises three subgenera Atrina Gray, 1842; Pinna Linnaeus, 1758 and Streptopinna von Martens, 1880 (OBIS Indo-Pacific Molluscan Database 2006). At the coasts of South Vietnam two Pinnidae species are found. They are Atrina vexillum (Born, 1778) (= Pinna nigra Dillwyn, 1817; Pinna nigra Chemnitz, 1785; Pinna vexillum Born, 1778; Atrina Okan and Hosgor, 2009) and Pinna trigonium Dunker, 1852 (= Pinna fumata Reeve, 1858; Pinna philippinensis Reeve, 1858). Shells of genus Pinna bivalves reach a very large size, up to $120 \mathrm{~cm}$ in length for Pinna nobilis (Zavodnik et al., 1991, cited by Garcia-March

Received: November 3, 2011 ; Accepted December 17, 2011

Corresponding author: Alla V. Silina

e-mail: allasilina@mail.ru

$1225-3480 / 24412$ et al., 2002). Their valves are thick and solid. Shells are inflated and variable in shape from triangular to hatchet-shaped or subglobular. All species have the same mode of life living vertically embedded in the bottom sediments, usually mud or muddy sand (Yonge, 1953; Purchon and Purchon, 1981). Pinna bivalves commonly stand point-first in the sea bottom in which they live, anchored by net of byssus threads. They are shallow infaunal suspension feeders (Yonge, 1953).

Little is known about $P$. trigonium. Usually synonymy is referred (Hedley, 1924; Rosewater, 1961; Huber, 2010). Studies about biology and ecology of this species are few (Malakhov et al., 1985; Dorofeeva et al., 1987). As a rule, bivalves of the genus Pinna live vertically embedded in the ground, however, $P$. trigonium was found not only in the ground, but also among the biofouling of the sunken vessel (Silina, 2010).

A. vexillum is a cosmopolitan Indo-Pacific species. It is found from East Africa, including Madagascar, the Red Sea and the Persian Gulf, to eastern Polynesia; north to Japan and Hawaii, and south to Queensland and New Caledonia (Hedley, 1924; Habe, 1968; Morris 
and Purchon, 1981; Abbott and Dance, 1982; Bernard et al., 1993; Huber, 2010). Common name of $A$. vexillum is Indo-Pacific pen shell. A shell of $A$. vexillum reaches large size and usually attains $30 \mathrm{~cm}$ ( $\max 48 \mathrm{~cm}$ ) (Poutiers, 1998). This bivalve mollusk is characterized by elongated, wedge-shaped shells (Poutiers, 1998). Its dorsal margin is usually nearly straight, posterior margin is broadly oval to somewhat truncate in outline. Ventral margin is broadly convex posteriorly and concave near the umbones, often strongly lobate in medium-sized and large specimens. Outside of valves it has 10-17 main radial ribs, often bearing scale-like spines, and weaker interstitial riblets. Internal nacreous layer is moderately strong, undivided and occupied the anterior half or $2 / 3$ of valves. Hind margin of posterior adductor scar is slightly protruding beyond the nacreous area. Protrusion of adductor scar is more developed in mature specimens. Colour of the outside surface of the valves varies from dark reddish-brown to nearly black, usually dull. Shell is semitranslucent and reddish purple when it is viewed with transmitted light. Interior colour varies from dark brown to black, iridescent on nacreous area.

Although details of the classification of Pinnidae have recorded (e.g., Hedley, 1924; Yonge, 1953; Bernard et al., 1993; Purchon and Purchon, 1981; Abbott and Dance, 1982; Okan and Hosgor, 2009, etc.), there are many discussions concerning Atrina vexillum. Originally, it was named $P$. vexillum Born, 1778 and similar specimens as $P$. nigra Dillwyn (1817). Then some researches considered that it is the type species of Atrina, and it was recombined as A. vexillum (Born, 1778) and A. nigra (Okan and Hosgor, 2009). Probably Pinna is more modified and Atrina the more primitive form (Hedley, 1924). The Pinna has an elongated shell with a longitudinal crack filled with a cartilage in the middle of each valve, and Atrina has shorter shells without any such crack (Gray, 1842, cited by Hedley, 1924). Additionally Hedley (1924) indicated that the essential Pinna characters are the shoulder of the shell towards the apex, which is externally angled and fissured, while that of Atrina is rounded and entire. Inside the valve,
Pinna has a long narrow sinus which extends through the middle of the nacreous tract for the most portion of its length, while the nacreous tract of Atrina is not thus cleft. Also, Atrina is distinguished from the Pinna by the lack of any grooves in the nacreous lining of the shell, and by the central positioning of the adductor scar. However, biogeographical distribution and morphological variations in the $A$. vexillum bivalves are very broad. Therefore, up to now, sometimes, researchers divide the mollusks that look like A. vexillum on two groups of P. nigra and $A$. vexillum. Now, for Atrina Gray, 1842 the type species is Pinna nigra Dillwyn, 1817. It is not unique case when Pinnidae species originally described as a Pinna was redescribed as Atrina, for example, Atrina affinis (Sowerby, 1821) (= Pinna affinis Sowerby, 1821) (Okan and Hosgor, 2009).

Morphological variations in bivalves are increasingly the focus of diverse ecological studies. Shape in bivalves is a key morphological characteristic that reflects both phylogenetic history and life habits. Comparison of different morphological characteristics of bivalves is very useful for distinguishing species. Therefore, this study used a morphometric approach to document patterns of phenotypic change through the specimens of Pinnidae inhabiting local settlement in the bottom sediments at the coasts of An Thoi Archipelago (south-eastern Gulf of Thailand, South Vietnam), in that way excluding intraspecific variations among different populations along a wide geographical range. Additionally, to answer the following questions: are there intraspecific morphological variations within populations, and is weight and linear growth of $P$. trigonium and $A$. vexillum isometric, the trends of morphometrical changes of specimens of these species during their life were studied.

\section{MATERIALS AND METHODS}

Bivalve specimens of genus Pinna were sampled at the coasts of An Thoi Archipelago (south-west Vietnam, the south-east Gulf of Thailand (= Siam Bay)), mainly near Hon Vong Island. A depth was 6-7 $\mathrm{m}$. The generic definition was made by Dr. Nam 
(Institute of Marine Researches, Nha Trang City, Vietnam). The Pinnidae specimens distinguished as $P$. trigonium were 12 ind., A. vexillum were 33 ind. and $P$. nigra were 20 ind.

To study inter- and intraspecific morphological variations of Pinnidae species nine morphometric characteristics were measured on each individual. They were length (L), height $(\mathrm{H})$ and width (D) of mollusk shell, total wet weight of the mollusk $\left(\mathrm{W}_{\text {total }}\right)$, wet weight of posterior adductor muscle $\left(\mathrm{W}_{\text {muscle }}\right)$, wet weight of the rest of the soft tissues ( $\mathrm{W}_{\text {soft tissues }}$ ), weight of the left and right valves, and total shell weight. Besides, such ratios between parameters of mollusk as $\mathrm{W}_{\text {muscle }} / \mathrm{W}_{\text {total }}, \mathrm{W}_{\text {soft tissues }} / \mathrm{W}_{\text {total }}, \mathrm{W}_{\text {muscle }} / \mathrm{W}_{\text {soft }}$ tissues, $\mathrm{H} / \mathrm{L}$ and $\mathrm{D} / \mathrm{L}$ were calculated for each specimen and used for Cluster analysis.

To study intraspecific morphological variations in each Pinnidae species the trends of morphometrical changes of specimens of these species during their growth were revealed by regression analysis.

\section{RESULTS AND DISCUSSION}

\section{Interspecific morphological variations}

The specimens of $P$. trigonium are distinctly separated off $A$. vexillum individuals, and it was not problem to determine $P$. trigonium in the waters of Vientam. Really, cluster analysis of the bivalve specimens of the genus Pinna sampled at the same place revealed that mollusks determined as $P$. trigonium separated from specimens of $P$. nigra and A. vexillum at a very high level (Fig. 1). Euclidean distance between these groups was 60-325. However, the specimens of $P$. nigra and $A$. vexillum did not spite up to groups. It allows concluding that $P$. nigra and $A$. vexillum bivalves inhabiting the bottom sediments near the coasts of South Vietnam are the single species, A. vexillum, as it is assumed now.

However, each group: (1) of $P$. trigonium individuals and (2) of $A$. vexillum specimens divided into tree subgroups at high level (Fig. 1). Thus, $P$. trigonium group consisted of subgroups: (1) $2,3,5$, and 6 ; (2) 4 , 7, 8, 10 and 11; and (3) 9 and 12 specimens (see Fig. 1). And $A$. vexillum group consists of subgroups: (1) from $A$. vexillum 1 to $P$. nigra 8; (2) from $A$. vexillum
4 to $P$. nigra 17; and (3) from $A$. vexillum 7 to $A$. vexillum 10 (see Fig. 1). It was found that such subgroups of $A$. vexillum unified the specimens with the similar morphometric parameters: small, medium and large within the population, though there were no evident divisions into subgroups in the size distribution of the population (Fig. 2). The same was revealed for $P$. trigonium specimens. Thus, besides the interspecific morphological variations the species also have significant intraspecific morphological variations even in the same population.

\section{Intraspecific morphological variations}

At the study population, the total wet weight of $P$. trigonium varied from 262 to $1590 \mathrm{~g}(559 \pm 118 \mathrm{~g}$ on the average), wet weight of the soft tissue was 32-132 g $(74 \pm 10 \mathrm{~g})$ and wet weight of the posterior adductor muscle was 7-25 g (15 $\pm 2 \mathrm{~g})$ in 1986 (Silina, 2010). The shell length varied from 249 to $377 \mathrm{~mm}$ (303 $\pm 15 \mathrm{~mm}$, Fig. 2), the height of the shell was $121-172 \mathrm{~mm}(139 \pm 5 \mathrm{~mm})$, and the shell width was $33-52 \mathrm{~mm}(43 \pm 2 \mathrm{~mm})$. Tissue wet weight was $8.3-20.0 \%$ of total wet weight, that is lower than for Pinna nobilis (Garcia-March et al., 2007) and the wet weight of the posterior adductor muscle was $1.6-4.6 \%$ of total wet weight and $16.8-26.8 \%$ of tissue wet weight, that is higher than for Pinna nobilis (Garcia-March et al., 2007).

The ratio of the weight of soft tissues to shell weight of $P$. trigonium was permanent $(\mathrm{P}<0.001)$ during mollusk life (Fig. 3). The ratios of the soft tissues and posterior adductor muscle weights to total weight decreased $(\mathrm{df}=1, \mathrm{~F}=1.30$ and $1.39, \mathrm{P}=$ 0.28 and $0.25, \mathrm{~N}=12$, regression analysis) under mollusk growth (Fig. 3). It is means that the proportion of soft tissues in total weight declines during mollusk life. The growth of total and posterior adductor muscle weights was not isometric, as the calculated exponents in the equations, which describe changes of these mollusk parameters with increase shell length, were $>3$ and $<3$, relatively (Table 1 ). In contrast, the growth of soft tissues and shell was practically isometric, the exponents were about of 3 (Table 1). Besides, the shell height of the P. trigonium 
Table 1. F

vexillu

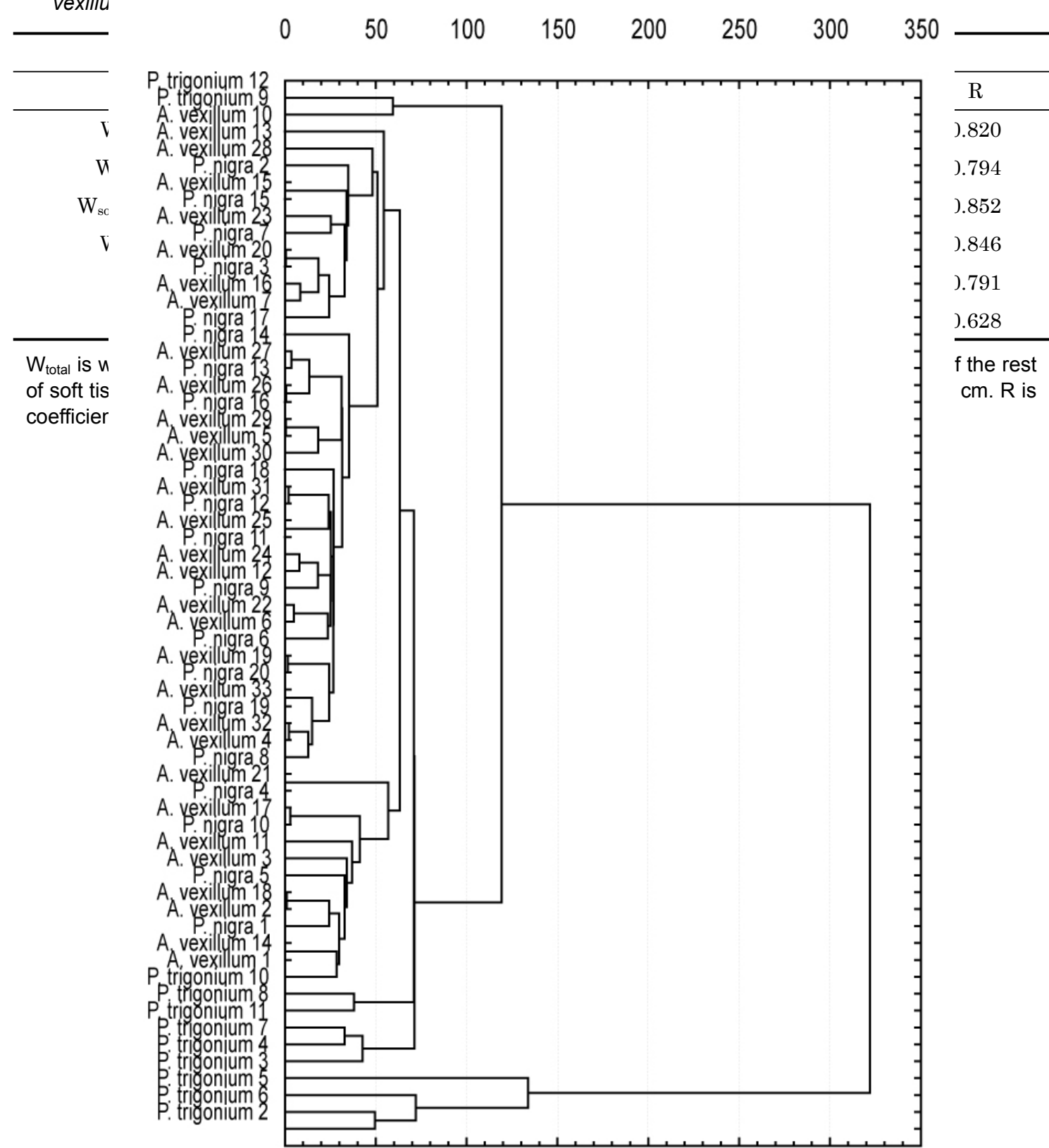

Fig. 1. Tree diagram of clustering analysis of the bivalve specimens of the genus Pinna sampled at the south-east Gulf of Thailand.

also did not change isometrically with shell length increase during mollusk life, as the exponent was many less than 1 (Table 1). It means that shell of the $P$. trigonium becomes more prolonged with increase its age. However, the shell convex is proportional to the shell length during all mollusk life, as exponent was practically equal to 1 (Table 1 ).

At the study population, the total wet weight of $A$. vexillum varied from 82 to $500 \mathrm{~g}(236 \pm 18 \mathrm{~g}$ on the average), the wet weight of soft tissues was 15-105 g $(41 \pm 3 \mathrm{~g})$ and wet weight of the posterior adductor muscle was 5-30 g (13 $\pm 1 \mathrm{~g})$ (Silina, 2011). The shell 
Table 1. Relationships between morhpometric parameters of the pen shells, both Pinna trigonium and Atrina vexillum, sampled at the coasts of An Thoi Archipelago, south-eastern Gulf of Thailand

\begin{tabular}{cccc}
\hline \multicolumn{2}{c}{ Pinna trigonium, $\mathrm{N}=12$} & \multicolumn{2}{c}{ Atrina vexillum, $\mathrm{N}=53$} \\
\hline Relation & $\mathrm{R}$ & Relation & $\mathrm{R}$ \\
\hline $\mathrm{W}_{\text {total }}=0.00275 \mathrm{~L}^{3.563}$ & 0.907 & $\mathrm{~W}_{\text {total }}=0.160 \mathrm{~L}^{2.560}$ & 0.820 \\
$\mathrm{~W}_{\text {muscle }}=0.0017 \mathrm{~L}^{2.6461}$ & 0.8731 & $\mathrm{~W}_{\text {muscle }}=0.010 \mathrm{~L}^{2.498}$ & 0.794 \\
$\mathrm{~W}_{\text {soft tissues }}=0.00327 \mathrm{~L}^{2.913}$ & 0.887 & $\mathrm{~W}_{\text {soft tissues }}=0.020 \mathrm{~L}^{2.674}$ & 0.852 \\
$\mathrm{~W}_{\text {shell }}=0.00989 \mathrm{~L}^{3.086}$ & 0.853 & $\mathrm{~W}_{\text {shell }}=0.130 \mathrm{~L}^{2.466}$ & 0.846 \\
$\mathrm{H}=3.6804 \mathrm{~L}^{0.393}$ & 0.559 & $\mathrm{H}=1.582 \mathrm{~L}^{0.704}$ & 0.791 \\
$\mathrm{D}=0.1496 \mathrm{~L}^{0.982}$ & 0.871 & $\mathrm{D}=0.698 \mathrm{~L}^{0.614}$ & 0.628 \\
\hline
\end{tabular}

$W_{\text {total }}$ is wet total weight, $W_{\text {muscle }}$ is wet weight of posterior adductor muscle, $W_{\text {soft tissues }}$ is wet weight of the rest of soft tissues $(\mathrm{g})$, and $W_{\text {shell }}$ is shell weight, $g$. $L$ is shell length, $H$ is shell height and $D$ is shell width, cm. $R$ is coefficient of correlation, and $\mathrm{N}$ is number of specimens.
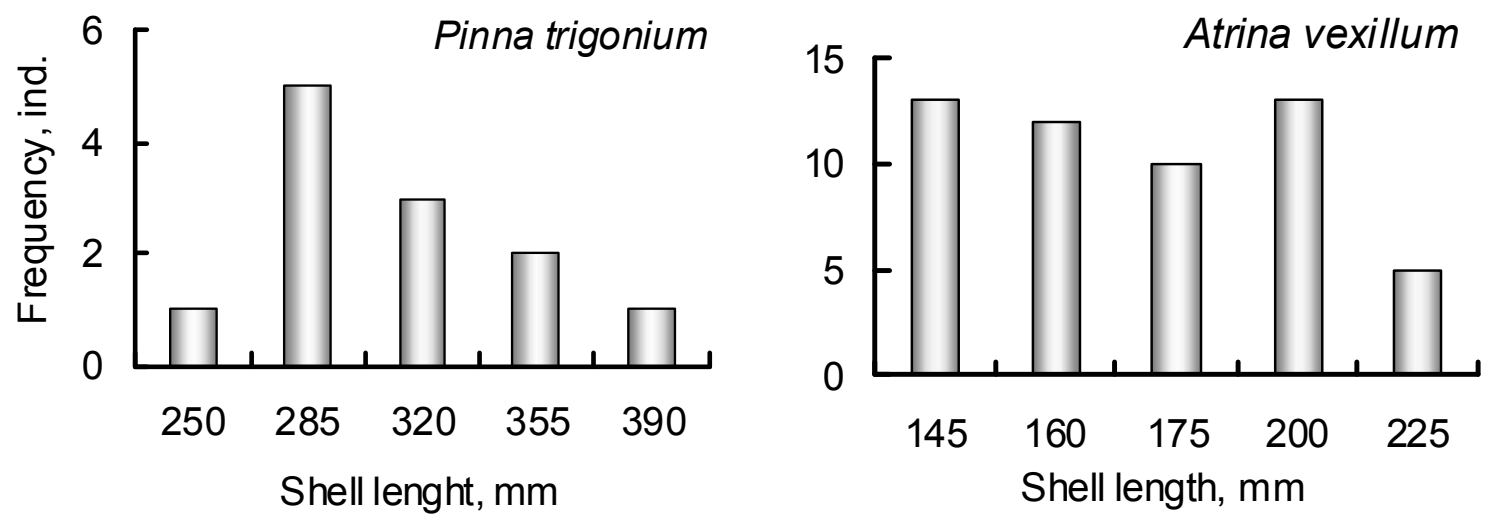

Fig. 2. Size-frequency distributions of the populations of Pinna trigonium and Atrina vexillum at the south-east Gulf of Thailand.

length varied from 131 to $224 \mathrm{~mm}(172 \pm 5 \mathrm{~mm})$ (Fig. 2), the height of the shell was $85-140 \mathrm{~mm}(116$ $\pm 3 \mathrm{~mm})$, and shell width was $27-49 \mathrm{~mm}(40 \pm 1$ $\mathrm{mm})$. The weight of soft tissues was $10.7-25.0 \%$ of total weight, that is lower index than that for Pinna nobilis (Garcia-March et al., 2007), but higher than for $P$. trigonium (Silina, 2010) and the weight of posterior adductor muscle was $3.1-7.7 \%$ of total weight and $19.0-37.0 \%$ of the weight of soft tissues, it is higher index than that for $P$ nobilis and $P$. trigonium (Garcia-March et al., 2007; Silina, 2010).

In contrast to $P$. trigonium, the ratio of the weight of soft tissues to shell weight was not permanent for A. vexillum, it increased ( $\mathrm{df}=1, \mathrm{~F}=2.19, \mathrm{P}=0.14$, $\mathrm{N}=53$, regression analysis) during mollusk growth (Fig. 4). The ratios of both soft tissues and posterior adductor muscle weights to total weight were statistically significantly permanent during mollusk life (Fig. 4). The growth of total weight, and the weights of $A$. vexillum mollusk's parts (soft tissues, posterior adductor muscle and shell) was not isometric with shell length increase, as the exponents were many less than 3 (Table). Classical allometric model had no supported for other Pinnidae species, too (Silina, 2010, 2011; Rabaoui et al., 2007). Moreover, the linear parameters of the A. vexillum also did not change isometrically during mollusk life, as the exponents were many less than 1 (Table 1). It means that shell of the A. vexillum becomes more prolonged and less convex (gibbous) with increase its length.

Thus, though various species of family Pinnidae 

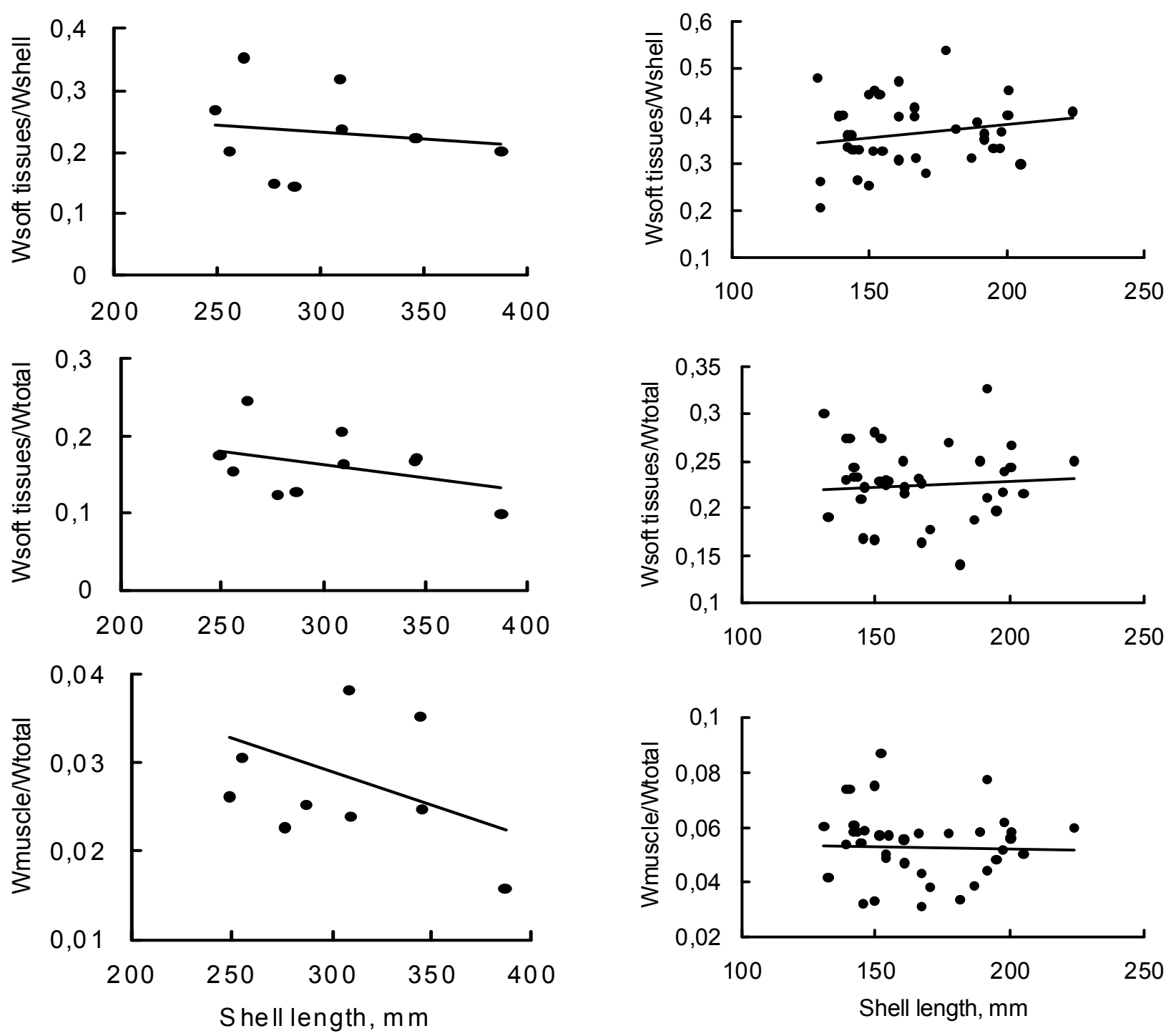

Fig. 3. Trends of ratios between wet weight of soft tissues to shell weight, wet weight of soft tissues to total wet weight, and wet weight of adductor muscle to total wet weight of Pinna trigonium with its shell length increase. $\mathrm{N}=12$.

grow under different rules of changes of ratios between the organs during mollusk life, and the proportions of the organs vary with increase mollusk shell length, the growth of the studied pen shell species is not isometric. It is the most probable reason for the appearance of the intraspecific morphological variations and division of all specimens into size-specific subgroups in the population. Possibly, the revealed disintegration of population on

Fig. 4. Trends of ratios between wet weight of soft tissues to shell weight, wet weight of soft tissues to total wet weight, and wet weight of adductor muscle to total wet weight of Atrina vexillum with its shell. $\mathrm{N}=53$.

mollusk development.

\section{ACKNOWLEDGEMENTS}

I thank Dr. Nam (Institute of Marine Researches, Nha Trang City, Vietnam) by the species definition of sampled mollusks and Dr. L.A. Pozdnyakova (A.V. Zhirmunsky Institute of Marine Biology FEB RAS) for measurement of bivalve parameters. 


\section{REFERENCES}

Abbott, R.T. and Dance, S.P. (1982) Compendium of seashells. E.P. Dutton Inc. New York. 311 pp.

Bernard, F.R., Cai, Y.Y. and Morton, B. (1993) Catalogue of the living marine bivalve molluscs of China. Hong Kong University Press, Hong Kong. 121 pp.

Dorofeeva, L.A., Pozdnyakova, L.A. and Silina, A.V. (1987) Dependence of growth rate and calcium-magnium ration in Pinna fumata shells on environmental temperature. Biulleten' Moskovskogo obshchestva ispytatelei prirody. Otdel Geologicheskii (Bulletin of the Moscow Society of Naturalistes. Section Geology), 62(6): 109-115. [in Russian]

Garcia-March, J.R., Garcia-Carrascosa, A.M., Cantero, A.L.P. and Wang, Y.G. (2007) Population structure, mortality and growth of Pinna nobilis Linnaeus, 1758 (Mollusca, Bivalvia) at different depths in Moraira Bay (Alicante, Western Mediterranean). Marine Biology, 150(5): 861-871.

Garcia-March, J.R., Garcia-Carrascosa, A.M. and Pena, A.L. (2002) In situ measurement of Pinna nobilis shells for age and growth studies: A new device. Marine Ecology-Publicazioni della Stazione Zoologica di Napoli, 23(3): 207-217.

Habe, T. (1968) Shells of the Western Pacific in color. Vol. 2. Hoikusha Publishing Co., LTD. Japan. Osaka. 233 pp.

Hedley, C. (1924) A revision of the Australian Pinnidae. Records of the Australian Museum, 14(3): 141-153.

Huber, M. (2010) Compendium of bivalves. A full-color guide to 3,300 of the World's Marine Bivalves. A status on Bivalvia after 250 years of research. ConchBooks, Hackenheim, Germany. 901 pp.

Malakhov, V.V., Yakovlev, Yu. M. and Blinov, S.V. (1985) Studies of the biology of commercial bivalve mollusks during IX cruise of the R/V "Berill" in the coastal waters of South Vietnam. Soviet Journal of Marine Biology, 3: 71-74.

Morris, S. and Purchon, R.D. (1981) The marine shelled mollusca of West Malaysia and Singapore. Part 3. Bivalvia. The Journal of Molluscan Studies, 47(3): 322-327.
Okan, Y. and Hosgor, I. (2009) Early Eocene (middle-late Cuisian) Molluscs assemblage from the Harpactcarcinid beds, in the Yoncali formation of the Cankiri Basin, central Anatolia, and implications for Tethys paleogeography. Geological Bulletin of Turkey, 52(1): 1-9.

Poutiers, J.M. (1998) Bivalves (Acephala, Lamellibranchia, Pelecypoda). In: FAO species identification guide for fishery purposes. In: (ed. by Carpenter, K.E. and Niem, V.H.) The living marine resources of the western central Pacific. Vol. 1: Seaweeds, corals, bivalves and gastropods. pp. 123-141. FAO. Rome.

Purchon, R.D. and Purchon, D.E.A. (1981) The marine shelled mollusca of West Malaysia and Singapore. Part 1. General introduction and an account of the collecting stations. The Journal of Molluscan Studies, 47(3): 290-312.

Rabaoui, L., Zouari, S.T., Katsanevakis, S. and Ben Hassine, O.K. (2007) Comparison of absolute and relative growth patterns among five Pinna nobilis populations along the Tunisian coastline: an information theory approach. Marine Biology, 152(3): 537-548.

Rosewater, J. (1961) The family Pinnidae in the Indo-Pacific. Indo-Pacific Mollusca, 1(4): 175-226.

Silina, A.V. (2010) Spatial and temporal changes in the population structure of bivalve Pinna fumata at the South Vietnam. In: Proceedings of the International Conference Marine Biodiversity of East Asian Seas: Status, Challenges and Sustainable Development. Nha Trang, Vietnam, December 6-7, 2010. pp. 98-100. Nha Trang.

Silina, A.V. (2011) The Indo-Pacific pen shell Atrina vexillum in south-eastern Siam Bay (South China Sea). In: Proceedings of the International Conference Coastal Marine Biodiversity and Bioresources of Vietnam and Adjacent Areas to the South China Sea. Nha Trang, Vietnam, November 24-25, 2011. pp. 12-16. Nha Trang.

Yonge, C.M. (1953) Form and habit in Pinna carnea Gmellin. Phylosophical Transactions of the Royal Society of London. Ser. B. Biological Sciences, 237(648): 335-374. 